\title{
Nation Character Building through Physical Education: Lesson Learned From 2013 Indonesian National Curriculum
}

\author{
Wawan Sundawan Suherman \\ Faculty of Sports Science \\ Universitas Negeri Yogyakarta \\ Yogyakarta, Indonesia \\ wansuherman@uny.ac.id
}

\begin{abstract}
- the 2013 curriculum has fostered the integration of character building into the process of education, as character building is an essential part of the process. In this regard, there are five main virtues to develop including religiosity, independence, nationalism, communal culture or gotong royong, and integrity. As one of compulsory subjects in the 2013 curriculum, physical education is also responsible for character building. PE's character building role is both vital and right because one of PE's goals is to build character. In addition, it also has the tools to do so through physical activities and sports. $\mathrm{PE}$ has performed its character-building job in its learning process. It indicated by the results showing that $P E$ has successfully developed students' virtues. The character-building program in PE requires continuous development by using either theory-to-practice approach or practice-to-theory approach. However, as practice-to-theory approach frequently adopted for studies, the adoption of either theory-to-practice approach should be prioritized.
\end{abstract}

Keywords - nation character, 2013 national curriculum, physical education

\section{INTRODUCTION}

Indonesia is currently implementing the 2013 Curriculum designed in July 2014. The 2013 Curriculum took over the 2006 Curriculum or the Competence-Based Curriculum (KBK) which, according to the government of Indonesian Republic, was no longer suitable for current needs as well as the advancement of knowledge and technology. The 2013 Curriculum has been gradually implemented in all education levels since academic year 2013/2014. The Indonesian government expects that implementation of the 2013 Curriculum will lead to increased education quality in the country. Such high expectation is because the 2013 Curriculum was developed thoughtfully by following the ideal steps and considering various influential aspects. It is in line with the statement of Lund and Tannehil [1] claiming that the development of curriculum, a set of education plans, should be dynamic due to needs and changes that occur in society. However, in reality, curriculum changes in 2013 remain controversial issues among government, teachers, and academician. The issues include, for example, debatable interpretation of various concepts and designs of the 2013 Curriculum as well as dissimilar implementation of the curriculum among schools. Different understanding caused by the gap in the quality of teachers from different regions.
Despite controversy over its implementation, the design of the 2013 Curriculum is both vital and meaningful for the development of human capital as it is designed to develop all developmental aspects among students including the cognitive, psycomotoric, and affective aspects. According to The Minister of Education and Culture [2], the 2013 Curriculum develops not only students' skills and knowledge but also attitudes. The curriculum was designed to build Productive, Creative, Innovative, and Affective Indonesian people through an integrated reinforcement of Attitude, Skill, and Knowledge. One of critical aspects being developed by the 2013 Curriculum is character. As the key to one's success in life, character, that includes one's potential and attribute, should be developed since childhood. Citizens' characters determine the state of a nation. Therefore, building their characters becomes indispensable and requires continuous development and implementation.

Children have talents, capacities, abilities, and skills to develop through an education process. Gardner [3] stated that human beings were born with a range of potentials to develop. Development is necessary not only to help people solve their problems but also to create valuable things in the society. Hoer [4] added that all children have their own strengths and therefore schools need to let them build on their strengths.

The 2013 Curriculum has assigned Physical Education Sport and Health (PESH) subject to develop students' characters. PESH is a subject that contributes to students' character development [5]. It indicates the importance of PESH in promoting children's growth and development, which is in line with the result of the study conducted by The California Department of Education [6] stating that the physical well-being of students has a direct impact on their ability to achieve academically. That evidence have the proof we have been looking for: students achieve best when they are physically fit. Thousands of years ago, the Greeks understood the importance of improving spirit, mind, and body. In addition, NASPE [7] added that quality physical education programs are also important because they provide learning experiences that meet youngsters' developmental needs, which in turn helps to improve their mental alertness, academic performance, and readiness and enthusiasm for learning. It evidences that PESH is capable of developing students' character.

Referring to the above discussion, some questions are proposed for investigation in this article. The questions 
include: (1) What are character and nation's character building? (2) Why is PE responsible for character building in the 2013 Curriculum? (3) What is the result of character building through PE?

\section{CHARACTER AND NATION CHARACTER BUILDING}

Character is one of potentials being developed in the process of education. According to Amini [8], character and attitude building starts at one's birth and continues as he develops and grows more potentials resulting from his adaptation process to the environment. Wynne (as cited in Amini, 2011:2) mentioned that the word "character" comes from a Greek word meaning "to mark" and emphasizes on the application of the virtues in the form of action and behavior. According to Al-Gazhali [9], character has close relation to Akhlaq, one's spontaneity in performing action or inherent behavior in oneself that allows him to proceed actions easily without any deliberation. The good, commendable behavior is called good akhlaq whereas the evil one is called bad akhlaq. Therefore, character means behavior representing good moral quality inherent in oneself.

Lickona [10] defined character as a reliable inner disposition to respond to situations in a morally good way. She also added that character so conceived has three interrelated parts: moral knowing, moral feeling, and moral behavior. Hence, noble character starts from having knowledge of kindness, continues to having commitment to kindness, and finally commits an act of kindness. In other words, character refers to series of knowledge (cognitive), attitudes, motivations as well as behaviors and skills.

For reinforcing the implementation of character building in schools, there are 18 virtues of character to develop deriving from religion, Pancasila, culture, and purpose of national education. The character virtues include: (a) Religiosity, (b) Honesty, (c) Tolerance, (d) Discipline, (e) Hard Work, (f) Creativity, (g) Independence, (h) Democracy, (i) Curiosity, (j) Nationalism, (k) Patriotism, (l) Appreciation towards Achievement, (m) Friendliness/Communication, (n) Peace, (o) Fond of Reading, (p) Environment Care, (k) Society Care, and (1) Responsibility [11]. Referring to the definition of character and the 18 virtues as well as the importance of character in human life, schools are required to prioritize character building in the process of education. In addition, according to The Center of Policy Analysis and Synchronization of Research and Development Office at Ministry of Education and Culture [12], although the 18 virtues for nation's character building have been identified, schools can determine their own development priorities to carry on the precondition values being developed earlier. From 18 virtues, five main values of nation's character should become the priority in the process of education. The five priorities include: (a) religiosity, (b) nationalism, (c) independence, (d) communal culture (gotong royong), and (e) integrity. To develop those five main values of the nation, character building can be implemented in the 2013 Curriculum by integrating each subject's achievements, synergizing roles of each education institution, and having competent teachers and role models [13]. According to Lickona, there are three stages in national character building including moral knowing, moral feeling, and moral behavior [14]. Similarly, Ridwan also mentioned three stages in character building which include knowing the good, feeling the good, and doing the good [15]. The Ministry of Education and Culture has emphasized the adoption of top-down approach that is more intervening, bottom-up approach that involves exploration of best practice and habituation, as well as revitalization program that is more empowering. The three approaches should be integrated into classroom learning activities, cultural development of lesson plan, co-curricular activities, and extracurricular [16].

The National Character Education Movement based on the National Action Plan (RAN) for Nation Character Building which started in 2010 needs to be maintained, optimized, intensified, and developed. In regard to this need, Reinforcement of Character Education (PPK) program becomes so important that it needs to be done from now on by taking into account sustainability and continuity principles. There are three main approaches to PPK including class-based, school culture-based, and society-based approaches. The three approaches are tied one another as a complete unity. The approaches assist schools in designing and implementing PPK programs and activities [17].

\section{Character Building THROUGH PHYSICAL EDUCATION ON 2013 NATIONAL CURRICULUM}

Physical Education, Sports, and Health (PESH) is one of compulsory subjects in the 2013 Curriculum. However, instead of PESH, the term Physical Education (PE) will be used for discussion in this article. According to Kirk, McDonald, and O'Sullivan [18], people remain using the term PE as it identifies the key process to be educated in, about, and through movements as its learning tools. PE is one of school subjects which directs students towards understanding human movements including human and environment factors that influence and are influenced by the movements. The way people make use of their abilities is to function optimally in everyday lives as complete human beings. PE promotes individual and community well-being by empowering students to demonstrate healthy attitude and behavior through physical activities as part of overall education experience.

Human movement as PE's field of study comprises three dimensions including education about, through and in movement. While discussing about PE, Kirk, Macdonald, and O'Sullivan [19] mentioned at least five theoretical perspective for studying PE including behavioral, interpretative, critical, feminist, and post theories. Those five theories are inseparable and tied one another. The adoption of all five theories allows people to discuss and investigate the meaning of PE properly.

Name changing does not change PE's goal orientations. PE aims at creating students who are healthy both physically and spiritually, sportsmanlike, faithful and cognizant of God, as well as aware of healthy lifestyle. Students' moral development is defined as one of the educational goals in the PE curriculum, both in elementary and high school grades. At the same time, play and participation in physical activities are settings which could support a child's moral development. As supported by Shields and Bredemeier, PE can probably be the most important physical activity context for promoting moral development [20]. Referring to its goals, PE is noted as one of important and right subjects to build national character as managed in the 2013 Curriculum. 


\section{EFFECT OF PHYSICAL EDUCATION LEARNING ON CHARACTER BUILDING}

Theoretically, PE considered as the right subject to develop students' character as it uses physical activities and sports for learning. Physical activities and sports seen and believed to be the right tools to build such good virtues as honesty, discipline, nationalism, and cooperation. Character education program through physical education conducted using two approaches namely the application, modification, and formulation of theoretical framework tested in various physical activities, physical education and sports (theory into practice). Some theories tested in PE's character building include social learning, structural-development, and social psychological approaches [21]. Moreover, Hellison and Doolittle mentioned some common approaches to developing character education program that include; (a) Kohlberg's constructivist theory of moral development with preadolescent school children in play settings; (b) Giebink and McKenzie's behaviorist-oriented pro-social conceptual framework in a residential camp setting; (c) the combination of interaction morality and structural developmental moral education in an elementary school physical education program; and (d) a comparison of social learning and structural moral development in a children's sports camp. Then, the systematic formulation and development of character building generate frameworks (practice into theory). One of important results of the approach is the emergence of several learning model in PE such as Teaching Personal and Social Responsibility (TPSR), adventure education, cooperative learning in physical education, and sport education, which adopted by many PE practitioners to build character [22].

As assigned by the 2013 Curriculum, PE practically and implementation acted as a character builder. Ali Maksum stated that character building is one of the cores of physical education in schools; however, to date, PE learning practices by teachers have not been satisfactory [23]. Nevertheless, some researches showed that PE has taken part in character building. According to Mulyana and Suherman, the tendency of character building on physical education is characterized by the tradition of teachers conveying codes in learning process. The contents of this code can be classified into two behaviors, which are, general behavior, which consists of personal and social behavior; as well as special treatment, which consists of the routines that should be followed by students at any time during the learning process of physical education, both in the field and in the classroom [24]. Nuzulul Anwar concluded that PE can develop students' character virtues which include tolerance, discipline, cooperation, responsibility, religiosity compassion, respect, and manner by means of several methods such as modelling, gymnastic, prayer leaders, as well as smiling and greeting habit [25]. Ripto concluded the PE learning practices develop Junior High School students' virtues including discipline, sportsmanship, responsibility, manner, and social relation [26].

Results of the study show that PE has implemented character building in its learning process. As a result, some virtues like discipline, religiosity, tolerance, communal culture/cooperation, sportsmanship, and responsibility are improving. Data indicate that practice-to-theory approach was adopted more frequently than any other approaches. This approach build up a character-building model to formulate frameworks or theories. Therefore, there are abundant learning models to develop the character of students from primary to secondary schools. Nevertheless, only few studies have noted the adoption of theory-topractice approach resulting in limited numbers of theories to test or to act as the basis for testing the program being developed.

\section{CONCLUSION}

The above discussion defines character as virtues or dispositions inherent in oneself or a reliable inner disposition to respond to situations in a morally good way. It is also stated that character so conceived has three interrelated parts: moral knowing, moral feeling, and moral behavior. Therefore, noble character starts from having knowledge of kindness, which later continues to growing commitment to kindness and ends up performing it. There are five main virtues of nation's character to develop including religiosity, nationalism, independence, communal culture (gotong royong), and integrity. In the 2013 Curriculum, PE has significant roles as students' character builder. This role is right for PE as it has tools namely sports and physical activities necessary for character building. PE has successfully performed this role by developing such virtues as discipline, responsibility, religiosity, and tolerance among students. The practice-to-theory approach was adopted more frequently for researches on character education program and produce more learning models than the theory-to-practice approach.

\section{ACKNOWLEDGMENTS}

The author gratefully thank the Rector of UNY, FIK UNY Chairpersons, and YISSPESH Committee for valuable supports and contribution to the completion of this article.

\section{REFERENCES}

[1] J.L. Lund, D. Tannehill, Standard-based physical education curriculum development. Sudbury, MA.: Jones and Bartlett Publishing, 2005.

[2] Kemendikbud, Paparan Menteri pendidikan dan kebudayaan RI pada press workshop: Implementasi kurikulum 2013. Kemendikbud RI, Pondok Cabe, 14 Januari 2014.

[3] Pusat Kurikulum, Pengembangan dan Pendidikan Budaya dan Karakter Bangsa: Pedoman Sekolah, 2009, pp.9-10.

[4] H. Gardner, Multiple intelligences (Kecerdasan majemuk: Teori dalam praktik), alih bahasa: Drs. Alexander Sindoro. Batam Center: Penerbit Interaksara, 2003, pp.36-53.

[5] T.R. Hoerr, Becoming a multiple intelligences school (Buku kerja multiple intelligences). Penerjemah: Ary Nilandari. Bandung: Penerbit Kaifa, 2007, pp.14-16

[6] Bafirman, Relationships of Character and Physical Fitness Quality through 'Penjasorkes' Learning to Students of Elementary School. International Journal of Humanities and Social Science, Vol. 4, No. 11, September 2014, pp.198-204.

[7] California Department of Education, "State Study Proves Physically Fit Kids Perform Better Academically." http://www.riv.egreen.wednet.edu/RiverviewPEsite/pages/statestudy.ht $m$ dibuka 1 November 2005

[8] NASPE, "Moving into the Future: National Standards for Physical Education, $2^{\text {nd }}$ http://www.aahperd.org/naspe/template.cfm?template=publicationsnationalstandards_3.html\#, download on May 20, 2006. 
[9] M. Amini, Peran pengasuhan Guru pada pembentukan karakter anak sejak dini”. Downloaded August $4^{\text {th }}$ 2011, pp.1-10 http://pustaka.ut.ac.id/pdf artikel/T16509.pdf

[10] E. Saminah, "Implementai pendidikan karakter pada kurikulum PAUD" dalam Karakter sebagai saripati tumbuh kembang anak usia dini. Yogyakarta: Inti Media dan Pusdi PAUD Lemlit UNY. 2011, pp. 172 - 186.

[11] T. Lickona, Educating for Character: How Our School Can Teach Respect and Responsibility. New York: Bantam books, 1991, p. 51

[12] Pusat Analisis dan Sinkronisasi Kebijakan Setjen Kemendikbud, Konsep dan pedoman penguatan pendidikan karakter, Jakarta: Setjen Kemendikbud, 2017, pp 1-64.

[13] Kaimudin, "Implementasi pendidikan karakter dalam kurikulum 2013", Dinamika Ilmu, Vol. 14, No 1, Juni 2014

[14] T. Lickona, 1991, Opcit.

[15] M. Ridwan, Menyemai Benih Karakter Anak, 2012. http://www.adzzikro.com

[16] Puskurbuk Balitbang Kemendikbud, Pedoman Pelaksanaan Pendidikan Karakter. Jakarta: Kemendikbud, 2011, pp.1-72.

[17] Pusat Analisis dan Sinkronisasi Kebijakan Setjen Kemendikbud, Konsep dan pedoman penguatan pendidikan karakter. Jakarta: Setjen Kemendikbud, 2017, pp.1-64.

[18] D. Kirk, D. Macdonald, M. O'Sullivan, Handbook of physical education. Thousand Oaks: Sage Publication, 2006.

[19] D. Kirk, D. Macdonald, M. O’Sullivan, 2006, Opcit.
[20] K. Mouratidou, S. Goutza, D. Chatzopoulos, "Physical education and moral development: An intervention programme to promote moral reasoning through physical education in high school students". European physical education review, 2007, Vol. 13, No. 1, pp.41-56.

[21] Sri Winarni, "Pengembangan karakter dalam olahraga dan pendidikan jasmine", Cakrawala Pendidikan, Mei 2011, Th. XXX, Edisi Khusus Dies Natalis UNY, 2011, pp.124-139.

[22] D. Helison, S. Doolittle, "Moral education in the practice of sport and physical education", Sport and education: Tribute to Martin Lee. Coimbra University Press, 2007, pp.109-118.

[23] A. Maksum, "Pendidikan Karakter dalam pendidikan jasmani: Kaya substansi miskin implementasi”, Laporan penelitian LPPM Unesa, 2016.

[24] Mulyana, A. Suherman, "The analysis of physical education learning and environment of character education-based school". 1st Annual Applied Science and Engineering Conference UPI Bandung. IOP Publishing, 2017, Pg. 1-4.

[25] N. Anwar, Implementasi nilai-nilai karakter siswa pada pembelajaran PJOK di Madrasah Ibtidaiyah KH. A. Thohir Tumpang Malang. Skripsi PGMI FITK UIN Malang, 2016.

[26] Ripto, Implementasi mata pelajaran Pendidikan jasmani olahraga dan kesehatan terhadap pengembangan nilai-nilai karakter siswa smp. Journal of physical education and sport, JPES, 2013, Vol. 2, No. 1, , pp.205-210. http://journal.unnes.ac.id/sju/index.php/jpes 